Kohl: a Journal for Body and Gender Research

Vol. 1, No. 2 (Winter 2015)

\title{
A Muffled Scream: \\ Queer Affects in Abdellah Taïa's Salvation Army
}

\author{
Dina Georgis
}

\begin{abstract}
:
This paper reads Abdellah Taïa's Salvation Army, a semi-autobiographical film that chronicles the coming of age of a Moroccan boy through its queer affects. Set in both Morocco and Switzerland, Taïa's protagonist is neither a victim nor oppressed by the socio-economic and patriarchal conditions of his existence. His sexuality is naive and perverse, exploited and exploitative. Queer knowledge in this film breaks down at many levels. The effect of this confusion is the film's insistence on reading the narrative outside of easy sexual epistemologies.

This paper defines "queer" not simply in terms of sexual orientation but as an affective relationship to loss. Borne from the traces of sexual being, queer affects resist the domestication of the sexual for social recognition. They are the parts of us that refuse to be colonized into affable, upright subjects. In Salvation Army, the protagonist grows up to be gay, as we have come to understand this word, but his subjectivity remains ambivalent and in mourning.
\end{abstract}


Abdellah Taïa's debut film Salvation Army is a gay coming of age story. Screened at many international film festivals (Toronto, Venice, Reykjavik, Namur, Sao Paulo, and Geneva), the film is an adaptation of his autobiographical novel with the same title. Taïa's film, set in both Morocco and Switzerland, is an unabashed representation of boyhood homosexuality. What makes this film noteworthy at the outset is that it is an honest and unguarded representation of queer sexuality in the Arab world. Taïa is an openly gay native Moroccan who very consciously sets out to challenge Moroccan society through this film (Knegt 2013). His approach, it would seem, is not to hold back on or mince reality. He is aware that many might find his film shocking. Indeed, the story of his young protagonist is not easy to watch as violence and abuse permeates his reality. But in Taïa's words: "I'm not the only person to have lived this reality, nor am I the only one who sees it" (Frosch 2013, par 9). What Taïa is implying here is what others have said: sexuality in the Arab world is not mediated through discourse and knowledge structures but in unspoken modes of expression (Massad 2007). This difference is borne from a tradition of privileging experience and aesthetic expression over language, imposed as a doctrine of silence, especially for those who need their desires recognized safely and without threat of injury. However, the distinction between mediation and silence also becomes an oppressive tool.

For many, the cultural silence that surrounds Arab sexuality comes at high price. In the film, this high price is lived by Taïa's protagonist Abdellah. Abdellah's story is simple but thick with emotional complexity. As I will demonstrate in this article, Abdellah is neither a victim nor oppressed by the socio-economic and patriarchal conditions of his existence. He is naive and perverse, exploited and exploitative. In a time in history when Arab sexuality is so easily read through civilizational binaries of East and West, ${ }^{1}$ Taïa's film seems unburdened by the politics of sexuality. It is not defensive of Arab sexual repression, but neither does it position Western gay culture as the harbinger of freedom. Indeed, in Salvation Army, there are no queer heroes and no intelligible trajectory of better times. Queer knowledge in this film breaks down at many levels. The film, which bears its weight on the viewer, is relentlessly melancholic. As film reviewer Diego Costa aptly puts it: "It's a quiet thud of a film, which embraces, with grace and precision, the nastiness of growing up with desire stuck in one's throat like a muffled scream" (2014, par 1).

The film adapts the diptych structure of the novel: the first half chronicles Abdellah's queer teenage life at home in a poor Casablanca neighbourhood; the second fast forwards 10 years when Abdellah is arriving in Geneva, still penniless and alone on a graduate scholarship. Beyond the structure and the events in this coming of age story, the film's aesthetic strategies depart from the novel. With very little dialogue, it is hard to swallow and digest the film. Silent scenes linger a little too long, inviting

\footnotetext{
${ }^{1}$ See Al-Samman, Hanadi and El-Ariss, Tarek special issue on "Queer Affects." This issue is devoted to identifying the pitfalls of hegemonic thinking that locks Eastern sexuality as premodern in a binary with modern Western sexuality. The authors advocate for affective readings of sexualities that demonstrate the entanglements of culture under contemporary geo-political conditions.
} 
the viewer to behold the queer affect transmitted. The film's queer affect, as I shall define more explicitly later, is not experienced as articulable knowledge, but a felt knowledge of danger or loss. Abdellah's melancholy and confusion is transferred from his throat to ours. As such, the silence of the film may not only be an artistic device: language is not easily available to Abdellah. This remains as such even as an adult, when he becomes a literary scholar conversant in gay culture. In the novel, however, the young Abdellah narrates his private thoughts frankly, but never in open dialogue. $\mathrm{A}$ distinct line is drawn between what can be uttered in public and what can be thought in private. Much of part 1 of the novel, which tells the story of his family and childhood life, reads like an account of a teenager's diary, with specific dates and entries. Nothing is chastened - not the passionate but violent love that his parents shared, not his father's cruelty towards his wife and children, and not the pleasure that Abdellah took from being exploited. Abdellah's meanderings about his love for his family are unambiguous but nonetheless perplexing. His wild and shameless incestuous desire for his older brother, Slimane, though bluntly expressed, is disconcerting. In the novel, it is what is said that troubles and confuses; in the film, it is the unsaid that seems to have the same effect. Interestingly, neither language nor silence mollifies the reader's discomfort or provides an explanation of the protagonist's journey.

I am making this brief comparison between the novel and the film to articulate a point that came to me upon reading a review by Jay Weissberg: curiously, Weissberg wanted the film to be as "straightforward" as the novel (2103, par 1). In his words: "the pic largely jettisons the first-person narrative that allowed access to the protag's head, replacing it with distancing coldness not helped by emotionless perfs" (2013, par1). I was particularly struck by this comment - he liked having access to the protagonist's head, suggesting that he needed to understand Abdellah and found his silence in the film frustrating. The emotional distancing puzzled the reviewer who worried that it rendered the spectator a voyeur. In the book, Weissberg explains, Taiia comes out "unadorned by guilt or sensationalism and directly confronting Western expectations" (2013, par 2). In other words, Taïa is precluding the possibility of sexual voyeurism; instead, he is talking back to his readers by brazenly representing his sexuality without shame, an affect a Westerner might not expect from an Arab engaging in same sex encounters. For instance, with respect to the protagonist's teenage sexual encounters with older men, Taïa, in Weissberg's analysis, "presents these episodes as rites of passage in which Abdellah connects to his sexuality; later, he also understands them as problematic manifestations of repression and the power dynamic imposed by older guys on younger ones" (2013, par 4). Not only does Taïa claim his early sexual experiences openly, he, under Weissberg's logic, settles their meaning for the reader and ostensibly puts the reader at ease with a reassuring psychosocial interpretation. Notwithstanding my divergent analysis of the novel, Weissberg's argument suggests that he would prefer the viewer not to have interpretive discretion in the interest of a "correct" representation.

I am singling out Weissberg's review from others to help me articulate the pitfalls of reading Salvation Army, and Arab sexualities in general, from an anxious or defensive standpoint. Eve Sedgwick famously conceptualized such readings as "paranoid," which she took from Melanie Klein's 
psychoanalysis. For Sedgwick (2003), Klein illuminated how our relationship to the outside world is psychologically motivated. The paranoid position reads the world selectively, suspiciously, and tautologically, compelled to expose and find what is insidious. However, the desire of a reparative impulse is motivated by what is in excess of familiar epistemologies and historiographies. Reparative reading is open to surprise and hope - to see and experience what a reader may not have anticipated. With reparative reading, the external world is neither wholly "good" nor wholly "bad," but in relationship to one another. Reparative readings encourage a view of the world that is integrated, albeit contradictory and messy.

I do not want to make light or overlook the harmful consequences of epistemologies that shame and harm in stereotypical perceptions of Arab sexual victimization. Indeed, Edward Said in Orientalism famously illuminated how Occidental sexual knowledge required fantasies of Eastern sexuality as weaker, yet more dangerous, mysterious, and tantalizing. The East, Said argues, became a sanctioned place where one could look for sexual experience, otherwise frowned upon in Europe (1978). Travel photography of the Orient allowed armchair travelers to voyeuristically feast on the exotic enigmatic other, all the while constructing the people as inferior and needing to be rescued. Psychoanalytically speaking, Orientalist discourse projects its anxieties of the unknown outward, reducing the other to an object that conveniently serves the psyche. Conversely, a reading that insists on the certainty of sexual sovereignty or empowerment is arguably equally reductive and yields its own set of problems; namely, it overlooks what knowledge it depends on to render sexuality intelligible and forecloses what exceeds knowledge altogether when it assumes that all sexualities are fully knowable.

The legacies of Orientalism live on in the rise of gay imperialism invested in the epistemology of gay liberation. ${ }^{2}$ Understood as freedom from the proverbial closet of shame, which has stood as the symbol of a dark life with no future, to be queer and proud is to dare to live your life brazenly. It is to be able to say that repression and shame have been liberated and unhinged. In this way, being gay is a speech act. As Foucault once argued, what characterizes modern sexuality is that it is a truth to be discovered and, once knowable to the self, becomes incumbent upon the self to confess it to the outside world. Foucault arguably was identifying the "coming out" imperative, now hegemonic and imposed on non-Western groups, which Joseph Massad collectively labels the "Gay International" in Desiring Arabs. These groups, Massad argues, undermine traditional expression of same sex love, reducing them to sexual repression and cultural barbarism from which people need to be freed. Salvation Army, the novel, can render Abdellah living out the trajectory of gay liberation if read defensively from a paranoid standpoint; from a shaming and shameful past, he claims his sexual identity. But a reparative reading might view his adolescent proclivities not simply as repressed, but also as expressions of curiosity and experimentation. Indeed, the young Abdellah tests the limits and possibilities under oppressive difficult conditions under which he lived, and arrives not to a settled identity, but a subjectivity at peace with itself even as it is unfinished project.

2 See Dina Georgis' "Thinking Past Pride: Queer Arab Shame in Bareed Mista3jil." 
Arguably, a paranoid reading of Salvation Army offers relief in epistemological certainty, for the path of sexual oppression can lead to freedom. What gets lost or foreclosed in such normalizing readings are the queer affects of the film - affects that might encourage speculation and insight rather than epistemologically rehearsed truths. Indeed, a reparative reading of the film might identify the film's intelligence in its capacity in describing what is constitutively not very clear or coherent. Salvation Army situates itself not in the protagonist's head, but in his embodied affects. Being in someone's head makes things plain and clear, but only if we trust that what we say consciously is how it is. What drives the desires of subjectivity is a queer agency that is not made from a cognitive process, but unconscious desires, lived affectively and discernable in aesthetic expression where uncertainty is tolerated.

Queer affects, as I have argued in other works, ${ }^{3}$ are the remainders of loss and renounced carnal pleasure. Illegible to cultural constructions of desire, queer affects are in excess of what we would normally find sexually appealing. Indeed, they are a return to the site of abjection and to the incest ties. Queer affects are implicated in reciprocal relationality because it is only in connection to our childhood erotic attachments that we relinquish carnal ties in exchange for socially acceptable ones. In other words, renunciation of pleasure guarantees us access to community, recognition, and security in family, nation, or perhaps a queer community. In this exchange, however, what gets foreclosed is the "perversely" sexual - which is to say sexual pleasure without social value, which stands outside normative sense and without a knowable future. Queer could be understood as the effects of submitting to our queer affects and resisting the domestication of sexual hedonism for social belonging. When this happens we are unconsciously refusing to be subjugated into affable, upright subjects - we are choosing "madness" over the path of normative sanity. ${ }^{4}$ While choosing queerness subjects you to social condemnation and expulsion, it may be the only life that actually makes you feel sane. Adam Phillips reminds us that sanity is not always the path to happiness. Indeed, sanity, he proposes, is a "sickness of the soul" $(2005,28)$, always leaving us feeling impoverished.

In his oft-cited essay "Mourning and Melancholia," Freud understood melancholy as an experience of impoverishment ${ }^{5}$ a loss that cannot be fed because what has been lost is not even clear. As remainders of lost desire, queer affects offer clues to what has been relinquished. When they find expression or tear through the facades of sanity, their dispersions might be censored, cast out, and rendered wrong or monstrous. Queer affects, however, also offer an opportunity to feed what has been emptied out, to mourn loss, to move out of melancholy and repair the effects of loss on the psyche. Seizing this opportunity is a psychic challenge: with queer affects, both the grounds on which

${ }^{3}$ For an extended discussion on queer affects, see Dina Georgis' The Better Story: Queer Affects from the Middle East.

${ }^{4}$ Idem.

${ }^{5}$ Ann Anlin Cheng's The Melancholy of Race beautifully develops and expands Freud's concept of melancholia as a state of impoverishment. 
communities stand and the glue of shared values that ties people together are threatened. Indeed, the presence of affects attunes us to how our desire for community, which gives us security, is at odds with some of our other, more dangerous desires. Queer affects are not entirely sustainable in our everyday lives: we are social beings who rely on language, shared meaning, and community belonging. Indeed, I argue that Taïa's film is the story of how Abdellah is managing and repairing this negotiation - between his queer desires and his devotion to place and family - in ways that might not be recognizable through the strict terms of gay epistemology and the communities formed by it.

Taïa's protagonist is queer not because he makes sense, but because he does not. His desires are muffled screams: simultaneously naive and perverse, exploited and exploitative. What motivates his sexual rendezvous' with older men is also unclear and inconsistent. The older men present as sleazy and manipulative, and, with them, the young Abdellah is sometimes emotionally cold but willing to perform; at other times, however, he seeks them out. Abdellah is not exactly represented as a victim of these encounters, but neither does he always present as fully behind his actions. Sometimes, his sex acts are for pay (a watermelon for the family); other times, they are not. It is difficult to say whether Abdellah experiences these encounters as shameful, pleasurable or utilitarian. His most explicit and unambiguous attraction is for his older brother, Slimane. Although Abdellah's obsession with his brother is clearly sexual in nature, Slimane is also the prized and admired first-born son: he speaks French fluently, likes to read, gets to travel, and, of all the children, is the one who gets to have his own bedroom. The family seems aware of his obsession, but what they make of it is again unclear. Mother worries he would get caught and killed if caught snooping in Slimane's room; on the other hand, father walks in on his son while he is melancholically plucking the petals of a flower rhyming "he loves me, he loves me not." Instead of reprimanding Abdellah, he holds him, gently kisses him on the forehead, and tells him not to go to bed hungry. Indeed, he might even encourage his same sex encounters for pay. It is hard to know whether Abdellah's sexual interest in his brother is treated like a family open secret or normalized as part of a young man's sexual coming of age both might be true. Taia's film is not committed to representing the young Abdellah as completely oppressed or hampered with shame, but neither does he seem happy or safe.

I would like to turn our attention to the question of what it would mean to read shame in the film, not as threat to gayness, but as a secondary emotion to confusing queer affects. Shame, I suggest, exposes a queer affect or a socially unacceptable desire, and therefore threatens the bonds and norms of belonging. In other words, shame is the feeling that comes up when our queer affects come into contact with the outside world; thus, it must be negotiated. In this way, shame creates the conditions for insight and change. Shame should make us pause rather than compel us to surmount it. Sedgwick indeed argued that shame is generative. Not only does it attune us to painful individuation, but "toward uncontrollable relationality" as well because it sharpens one's sense of oneself when contact is broken and life itself is threatened $(2003,37)$. In Elspeth Probyn's words, feeling shame activates what matters because "whatever it is that shames you will be something that is important to you, an essential part of yourself' (2005, x). Shame always happens in relation, and thus gets us in touch with our deepest investments in each other. In shame, we become queerly 
undone. Our worries and concerns about our investments in relationality and our dependencies on the other and on our community become more transparent. Also, since shame always has an immediate bodily effect, it invites reflection, even creative reparation.

At home, Abdellah's queer perversions and shameful encounters are most discernable. His family life is marked by poverty, patriarchal hierarchies, and subscribed gender roles, to which he has an ambivalent relationship (sometimes they work in his interest, sometimes they do not). Among all the siblings, consisting of 4 or 5 sisters, a baby brother and Slimane, Abdellah is the only one who dwells in both the predominantly male public space of the town and the private domestic feminized space of home, sharing chores with his sisters under the formidable rule of his mother. Abdellah's loyalties are put to the test when he is forced to take his father's side after a night of domestic sexual violence between the married couple, represented as a regular occurrence. The following day, his father sends his dinner back to his wife through Abdellah, complaining that he is being punished by her and does not want to eat alone. When she retorts to her son that he should go to the kitchen and eat his father's unwanted meal, Abdellah is visibly heartbroken. Caught between the privileges of the men's world (he gets to have his father's discarded meal all to himself but with himself) and the warmth and bonding of the women's world, Abdellah chooses the women: he tells his mother he'd rather eat with them. After all, it is with them that he sleeps at night, where they are all tightly nestled around their mother on the living room sofa and floor. In loyalty to their victimized mother (with whom they all identify, including Abdellah), one of his sisters adds salt to his wound and cries out: "look girls, he's going to cry again." Abdellah is shamed because, of course, boys are not supposed to cry, and certainly not for being excluded by girls. I would like to suggest that Abdellah's grief is not simply a response to being alienated from feminine space; it is also the world to which he is bonded and attached - his community. If feeling shame is linked to what matters most to us, specifically the relationships that are part of us, then Abdellah's shame signifies his stakes in relationality. In this scene, his shame from his queerly gendered affects threatens the bonds of family life and his place in it.

In part 2 of the film, Abdellah is a young man in Geneva. He has left home to start a graduate degree. Arguably, in making this decision, he chooses the world of men, which makes certain freedoms possible, such as the privilege of leaving home, often not granted to women. But in Abdellah's case, the privilege of leaving home was not only made possible by virtue of the fact that he was a man, but also a gay man, a complicated privilege. On the last scene of part 1, Abdellah picks a white Swiss tourist up. He is on vacation with his brothers, but Slimane has taken off with a girl. The day before he abandons them, a conversation ensues on the beach. Here, Abdellah indicts Slimane for reading French novels and for insisting on speaking French, "the language of the rich," in Abdellah's words. "What use is French for me," asks Abdellah who is unmoved by Slimane's reasoning that "there's no harm in speaking French" and that it would help him leave Morocco and succeed in life. "You'll change your mind, I know you will," insists Slimane. And indeed, Abdellah does change his mind. 
Part 2 begins at a beach resort in Morocco, this time with his lover, a middle-aged Swiss professor. Abdellah is looking refined and speaking French elegantly, though his manner is muted and cold. If this is the kind of success his brother Slimane was talking about, then this opening scene demonstrates his thorny arrival. On a boat ride with his lover to visit a touristic sight, Abdalleh does not deny the tour guide's assumptions that his involvement with his European companion is for pay. He might accede to this fiction either because the homosexual contract the tour guide is alluding to between locals and Europeans is acceptable in Morocco and therefore safer not to rock the proverbial boat, or because Abdellah actually believes in the truth of the man's assessment of their relationship and that it is he who has been living a lie. When some time down the road, Abdellah accidentally runs in into his now ex-lover at the university and is accused of being exploitative and cruel for leaving, he again does not deny this reading, but does so with more intensity, somewhere between anger and pain. Abdellah, the adult, has been exploited and has also exploited. His insights are subtly communicated in the film. For instance, sitting on a park bench, penniless, homeless, and unable to ask his mother for help on a phone call to her, a middle-aged man sits beside him and starts to ask him where he is from. Abdellah is tense: it could be another pick up. He remains tense till the man shares his melancholic love story of how his Moroccan wife left him for not being rich enough. Upon hearing this, Abdellah's body immediately and visibly relaxes. The man, it turns out, wants absolutely nothing from him. In fact, Abdellah asks him where he can find shelter for the night at the Salvation Army.

If Abdellah is liberated sexually from repression, his "freedom" is neither palpable, nor is it on a linear or progressive trajectory. The closing scenes of the film are at the Salvation Army refuge, where he encounters more kindness. Arranged by the custodian of the shelter, Abdellah meets his new roommate on his second night at the shelter, who is also North African. Abdellah offers to share his orange with him, but the roommate wants to sing for him first. The song he chooses by the iconic Abdel Halim Hafez is well known to most Arabs. A common man who is considered to be the voice of the people, Abdel Halim Hafez rose to become one of the Great Four of Arab musicians. His style was radical and he was considered Egypt's first romantic singer. Indeed, his songs were inspirational during the protests of the 2011 uprisings in Egypt. The film then ends auspiciously in this mutual act of generosity as Abdellah listens to the song of one of the most revered singers of the Arab world, a world it would seem to which he is still deeply tied. This ending could be read as Abdellah's nostalgic relationship to his homeland, but it could also be suggestive of a return to home and community with a difference. Here, community and love is re-established through an intervention of kindness between the two displaced men.

Salvation Army's contribution to insights into complex Arab sexualities is made in the aesthetic strategies that the film offers. As one of the few available visual representations of Arab queerness, its strength lies in its ability to draw us in emotionally, creating the conditions for thoughtful reflection. My interest in reading the film reparatively vis-à-vis its queer affects is to advance a creative or insightful critique of the film, one that is neither reducible to gay epistemologies, nor naïve to their 
power on Arabs and other people of the global south. Abdellah is indeed negotiating the competing epistemologies of Eastern and Western. While this is always difficult, the postcolonial/diasporic condition of having to navigate a double consciousness, as Paul Gilroy argues (1993, 2005), can set the postcolonial subject on a creative path. This path is messy, especially in a historical context where gay consciousness is hegemonically imposed and, by and large, has not undergone an epistemic challenge. In Abdellah, we see a bewildered and curious child, then a young man who is unable to fully comply with the terms of either Eastern or Western epistemologies, and therefore struggling to fully belong in either cultural context. While this is painful, it creates the conditions for creativity and invention, something we abjure, says Phillips (1998), when we grow up.

For Taïa, what is at stake is not how queerness comes into an intelligible identity, though that surely helps abate the confusion, nor is he narrating a story that leads to queer emancipation. Rather, Salvation Army chronicles how his young protagonist must survive the world's unkindness to difference. The road that one must travel on this journey is painful because queer difference, as I have described it in this paper, is always met with social prohibition, which can render you "mad" if the price to accede to it is too high. Salvation Army shelters across the globe are sanctuaries for the mad and for the abjected. In the one that Abdellah stays in, he does not receive salvation, but empathy. What is staged here is not a missionary saving of the other, but a kind consideration of the other's vulnerabilities. Taïa's film does not offer the fantasy of liberation for queer Arabs, but something far more achievable. The film's ending is hopeful because it hints at how Abdellah's queer future may be forged in attendance to the losses he has endured. This is not a future set in a strict notion of what is better; rather, it is a defined by what might be possible if the journey is steered through the work of mourning and reparation. 


\section{References}

Al-Samman, Hanadi and El-Ariss, Tarek. 2013. "Queer Affects: Introduction." International Journal of Middle East Studies. 45: 205-209.

Cheng, Anne Anlin. 2001. The Melancholy of Race: Psychoanalysis, Assimilation and Hidden Grief. New York: Oxford Press.

Diego, Costa. 2014. "Salvation Army." Slant Magazine. March 18, 2014. http://www.slantmagazine.com/film/review/salvation-army Accessed August 7, 2015.

Foucault, Michel. 1978. The History of Sexuality. Translated by Robert Hurley. New York: Pantheon Books.

Frosch, Jon. 2013. "Exclusive interview: 'There is a place for gays in Islam." France 24. September 5, 2013. http://www.france24.com/en/20130905-venice-film-festival-abdallah-taia-gaymuslim-islam-homosexuality-morocco-arab-salvation-army Accessed August 7, 2015.

Georgis, Dina. 2013. The Better Story: Queer Affects from the Middle East. Albany: SUNY.

---. 2013. "Thinking Past Pride: Queer Arab Shame in Bareed Mista3jil." International Journal of Middle East Studies. 45: 233-251.

Gilroy, Paul. 2005. Postcolonial Melancholia. New York: Columbia University Press.

---. 1993. The Black Atlantic: Modernity and Double Consciousness. Cambridge: Harvard University Press.

Knegt, Peter. 2013. "Que(e)ries: 'Salvation Army' Director Abdellah Taia on The Challenges of Making a Queer Moroccan Film." Indiwire. September 23, 2013. http://www.indiewire.com/article/que-e-ries-salvation-army Accessed August 5, 2015.

Massad, Joseph. 2007. Desiring Arabs. Chicago: University of Chicago Press.

Phillips, Adam. 1998. Beast in the Nursery: On Curiosity and Other Appetites. New York: Vintage Books.

---. 2005. Going Sane. London: Penguin Books.

Probyn, Elspeth. 2005. Blush: Faces of Shame. Minneapolis, Minn.: University of Minnesota Press.

Said, Edward. 1978. Orientalism. New York: Vintage.

Sedgwick, Eve Kosofsky. 2003. Touching Feeling: Affect, Pedagogy, Performativity.

Durham, NC: Duke University Press.

Taïa, Abdellah. 2009. Salvation Army. Translated by Frank Stock. LA: Semiotext(e).

--- (dir). 2012. Salvation Army. 81 min. France, Morocco, Switzerland.

Weissberg, Jay. 2103. "Venice Film Review: 'Salvation Army'." Variety. September 3, 2013. http://variety.com/2013/film/global/salvation-army-review-venice-toronto-1200609534/ Accessed August 8, 2015. 